\title{
Asthma management: Are GINA guidelines appropriate for daily clinical practice?
}

\author{
Barbara P. Yawn ${ }^{a, b, *}$, Thys van der Molen ${ }^{c, d}$, Marc Humbert ${ }^{e}$
}

\author{
a Department of Research, Olmsted Medical Center, Rochester, MN, USA \\ ${ }^{\mathrm{b}}$ Department of Family and Community Medicine, University of Minnesota, Minneapolis, MN, USA \\ c Department of General Practice and Primary Care, University of Aberdeen, Aberdeen, Scotland \\ 'd Department of General Practice, University of Groningen, Groningen, The Netherlands \\ e Service de Pneumologie et Réanimation Respiratoire, Hôpital Antoine Béclère, Assistance \\ Publique-Hôpitaux de Paris, Université Paris-Sud, Clamart, France
}

Received 5 February 2005; accepted 18 April 2005

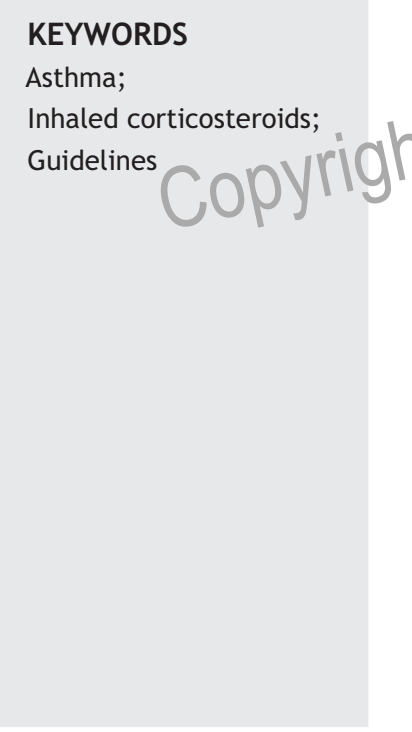

\section{KEYWORDS}

Asthma;

Inhaled corticosteroids;

\section{Introduction}

An estimated 1 in 20 people in the world now have asthma [1]. The prevalence of asthma is

\footnotetext{
* Corresponding author. Tel.: +1 507287 2758;

fax: +1 5072872722 .

E-mail address: yawnx002@umn.edu (B.P. Yawn).
}

\begin{abstract}
Summary An internationa grepp onilprimary care asthma experts, as well as pulmonologists ard alergises from Europe arid the US, met to discuss asthma manasencr t tocused on the primlary care Esfice. This paper summarizes their discussions. Accuracy of diagnosis and appropriateness of treatment is variable depending on the Calmical circumstances and patient group. The value of classifying Faitients based on baseline or static asthma severity scores remains controversial, and asthma management decisions based on symptom control appear to have greater practical utility in a primary care setting. Furthermore, it must be recognized that patients, caregivers and physicians may have differing, and possibly conflicting, goals for therapy. There are many initiatives to improve the quality of asthma management, for example, primary care-focused guidelines being developed by the International Primary Care Respiratory Group, and several groups are working on asthma control scores. In addition, new therapies may improve the options available for increasing compliance and reducing side effects. In conclusion, asthma management should be patient-focused, with outcomes relevant to improving the quality of life for people with asthma.

(c) 2005 General Practice Airways Group. Published by Elsevier Ltd. All rights reserved.
\end{abstract}

increasing in line with growing urbanization; there may be an additional 100 million people with asthma by 2025 [1]. In Europe, the prevalence of asthma has doubled in the last 10 years, and total asthma costs are approximately $\$ 21.65$ billion/year [2]. The majority of these costs relate to lost productivity (55\%), with out-patient care $(22 \%)$, anti-asthma drugs $(20 \%)$, and in-patient care $(3 \%)$ 
Table 1 List of participants.

\begin{tabular}{|c|c|}
\hline Participant & Affiliation \\
\hline $\begin{array}{l}\text { Dirkje S Postma, MD, PhD } \\
\text { (Meeting Chair) }\end{array}$ & $\begin{array}{l}\text { Professor, Department of Pulmonary Diseases, University Hospital Groningen, } \\
\text { Groningen, The Netherlands }\end{array}$ \\
\hline Peter Barnes, MD, DSc FRCP & $\begin{array}{l}\text { Head of Respiratory Medicine, National Heart and Lung Institute, Imperial } \\
\text { College, London, UK }\end{array}$ \\
\hline Gene L Colice, MD & $\begin{array}{l}\text { Director, Pulmonary, Critical Care and Respiratory Services, Washington Hospital } \\
\text { Center and Professor of Medicine, The George Washington School of Medicine, } \\
\text { Washington DC, USA }\end{array}$ \\
\hline Ronald Dahl, MD & $\begin{array}{l}\text { Professor, Department of Respiratory Diseases, Arhus University Hospital, Arhus, } \\
\text { Denmark }\end{array}$ \\
\hline Rob Horne, PhD, MRPharmS & $\begin{array}{l}\text { Professor of Psychology in Health Care and Director, Centre for Health Care } \\
\text { Research, Postgraduate Medical School, University of Brighton, Brighton, UK }\end{array}$ \\
\hline Marc Humbert, MD, PhD & $\begin{array}{l}\text { Service de Pneumologie et Réanimation Respiratoire, Hôpital Antoine Béclère, } \\
\text { Assistance Publique-Hôpitaux de Paris, Université Paris-Sud, Clamart, France }\end{array}$ \\
\hline Helgo Magnussen, MD & $\begin{array}{l}\text { Professor, Center for Pneumology and Thoracic Surgery, Großhansdorf Hospital, } \\
\text { Großhansdorf, Germany }\end{array}$ \\
\hline Paul O’Byrne, MD & $\begin{array}{l}\text { EJ Moran Campbell Professor and Chairman, Department of Medicine, McMaster } \\
\text { University, Hamilton, Ontario, Canada }\end{array}$ \\
\hline Søren Pedersen, MD, Dr DMSC & $\begin{array}{l}\text { Professor of Pediatric Respiratory Medicine, University of Southern Denmark, } \\
\text { Kolding Hospital, Kolding, Denmark }\end{array}$ \\
\hline Thys van der Molen MD, PhD & $\begin{array}{l}\text { GPIAG Professor of Primary Care Respiratory Medicine, Department of General } \\
\text { Practice and Primary Care, University of Aberdeen, Aberdeen, Scotland and } \\
\text { Associate Professor of Primary Care Medicine, Department of General Practice, } \\
\text { University of Groningen, Groningen, the Netherlands }\end{array}$ \\
\hline Sally Wenzel, MD & $\begin{array}{l}\text { Professor of Medicine, Co-Director, Weinberg Clinical Research Unit National } \\
\text { Jewish Medical and Research Center, University of Cotorado Healith Sciences } \\
\text { Center, Denver, CO, USA }\end{array}$ \\
\hline Barbara P Yawn, MD, MSc & 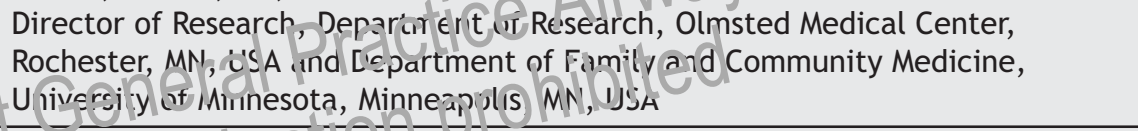 \\
\hline
\end{tabular}

responsible for the remainder [2]. This increase in asthma prevalence, and the dependence on out-patient care, makes asthma an increasingly important priority for the primary care physician.

In April 2004, an international group of experts in asthma care and asthma clinical research were invited by Altana Pharmaceuticals to meet in Amsterdam, The Netherlands. The group met to discuss concerns regarding the difficulties encountered by primary care physicians when trying to incorporate current asthma care guidelines, such as the Global Initiative for Asthma (GINA) and the National Heart Lung and Blood Institute guidelines (USA) [3,4], into their practices [5-8] Participants included primary care asthma experts as well as pulmonologists and allergists from Europe and the US (Table 1). This paper summarizes the discussions.

\section{Goals of asthma therapy}

The GINA and other national asthma guidelines recommend similar goals for asthma management
(Table 2) [3,4]. In order to meet these goals, patients need adequate and appropriate therapy. Inhaled corticosteroids (ICS) are the cornerstone of asthma pharmacologic therapy, and have the potential to reduce significantly asthma morbidity and mortality $[3,4]$. However, undertreatment of asthma with ICS is a considerable problem [5]. Undertreatment includes patients not receiving ICS therapy at all, receiving ICS therapy at too low a dose, or choosing to take less of their ICS medication than they have been prescribed.

Table 2 Goals of asthma management.

\begin{tabular}{|c|c|}
\hline $\begin{array}{l}\text { - Minimal chronic symptoms } \\
\text { - No emergency visits } \\
\text { activities } \\
\text { - Peak expiratory flow } \\
\text { circadian variation of less } \\
\text { than } 20 \%\end{array}$ & $\begin{array}{l}\text { - Minimal } \\
\text { exacerbations } \\
\text { - Minimum need for } \\
\text { as-required } \beta \text {-agonists } \\
\text { - Near-normal peak } \\
\text { expiratory flow } \\
\text { - Minimal adverse } \\
\text { effect of asthma } \\
\text { medication }\end{array}$ \\
\hline
\end{tabular}

Adapted from [3]. 
The Asthma Insights and Reality surveys were conducted between 1998 and 2001 in 29 countries in Western Europe, Central and Eastern Europe, Asia-Pacific, Japan and the USA, and included responses from 7786 adults and 3153 children with asthma [5]. The survey respondents were identified through national patient care registries or random digit dialing (USA). These surveys found that the majority of asthma patients, across all regions, did not achieve the GINA or NHLBI goals: little or no interference with activities; few symptoms; and very limited need for rescue medications. $[3,4]$ For example, in Western Europe and in the USA, many patients had significant symptoms with continued adverse impact on daily activities, and only approximately $23 \%$ and $15 \%$, respectively, were receiving ICS (Figure 1) [5]. In comparison, over $60 \%$ of patients in both regions were using shortacting $\beta$-agonists. For patients with severe asthma, only $26 \%$ and $20 \%$, respectively, were receiving ICS therapy [5]. A large proportion of the morbidity identified in these surveys could be avoided with regular use of appropriate anti-inflammatory therapy (ICS) in patients with persistent asthma $[4,5]$.

Estimated asthma mortality rates vary considerably by region: $36.7 / 100,000$ in China, $5.2 / 100,000$ in the USA and between $0.54 / 100,0.0 P$

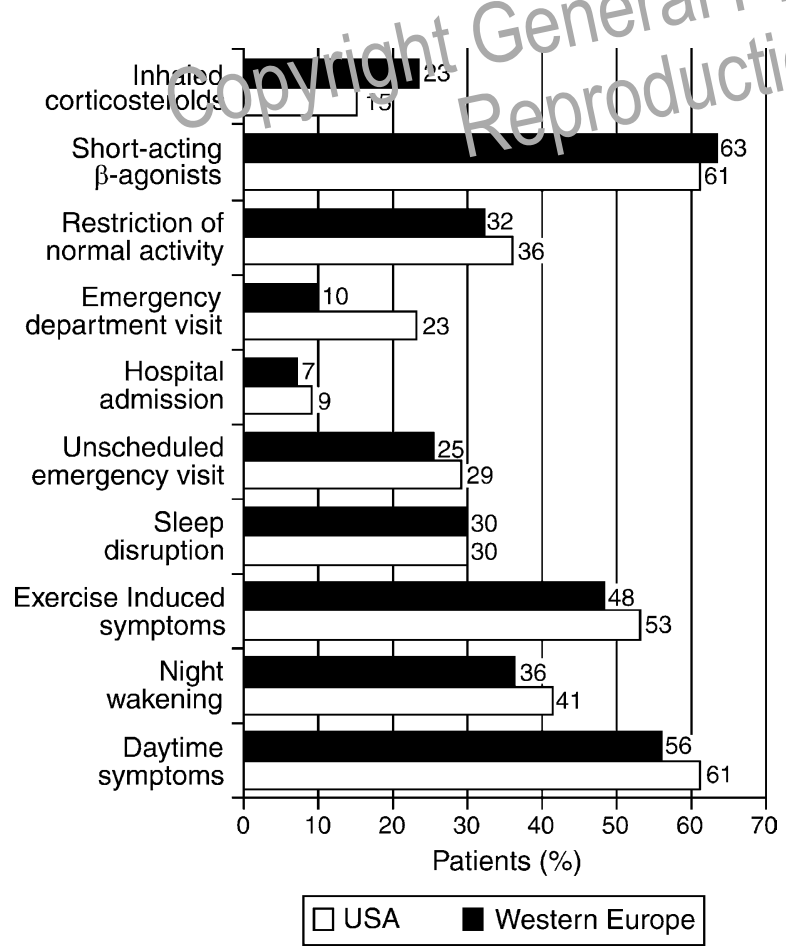

Figure 1 Findings of the Asthma Insights and Reality surveys for Western Europe and the USA in respect to symptoms, healthcare use and short-acting $\beta$-agonist and inhaled corticosteroid therapy. Adapted from [5].
(The Netherlands) and $8.7 / 100,000$ (Portugal) in Western Europe [1,2]. The majority of these deaths would be preventable with adequate treatment. For example, the low mortality rates seen in the Netherlands can be attributed to a comprehensive physician training scheme for asthma and COPD instigated in 1986. Since then, rates of asthma-related hospital admission and asthma mortality have declined for most patient groups [9]. A similarly successful translation of the GINA guidelines into practical office-based programs has also lowered rates of morbidity and mortality in Finland [10].

The GINA and NHBLI goals of asthma (Table 2) are currently not being met [5], often due to the under use of anti-inflammatory medications such as ICS in patients with persistent disease. Primary care physicians treat the whole spectrum of asthma severity, and the experiences of The Netherlands and Finland indicate that targeted interventions in the office setting can be successful in reducing asthma morbidity and mortality $[9,10]$.

\section{Asthma diagnosis}

A correct ciagnbsis oi asthma, with appropriate cheapy, can greatly improve patients' quality of life $[3,4] . \mid T h \in(-1)$, diagnfosed on symptom presentation alone, and pulmonary function is rarely investigated. For some patients, a diagnosis of asthma will be straightforward based on symptoms and history. However, a significant proportion of patients will have their diagnosis complicated by co-morbid illness or have non-specific symptoms that may vary considerably over time. Responsiveness to short-acting $\beta$-agonists should be demonstrated, and lung function testing is recommended where possible. Spirometry can be performed reliably and reproducibly in primary care offices [11-13], although most primary care practices do not have this facility. In the absence of spirometry, it may be useful to have objective repeated evidence of reversible airflow obstruction using a peak flow meter. Single peak flow readings are of very little use diagnostically, but serial measurements to assess peak flow variability and changes in the flow after treatment can be useful in diagnosing asthma. Exercise or methacholine challenge can be performed in those difficult cases when spirometry and peak flow assessment are insufficient. Although this test is seldom available in the primary care office, it is usually available in specialty centres.

The appropriateness of the diagnosis of asthma appears to be associated with age. In very 
Table 3 Differential diagnosis of asthma and COPD.

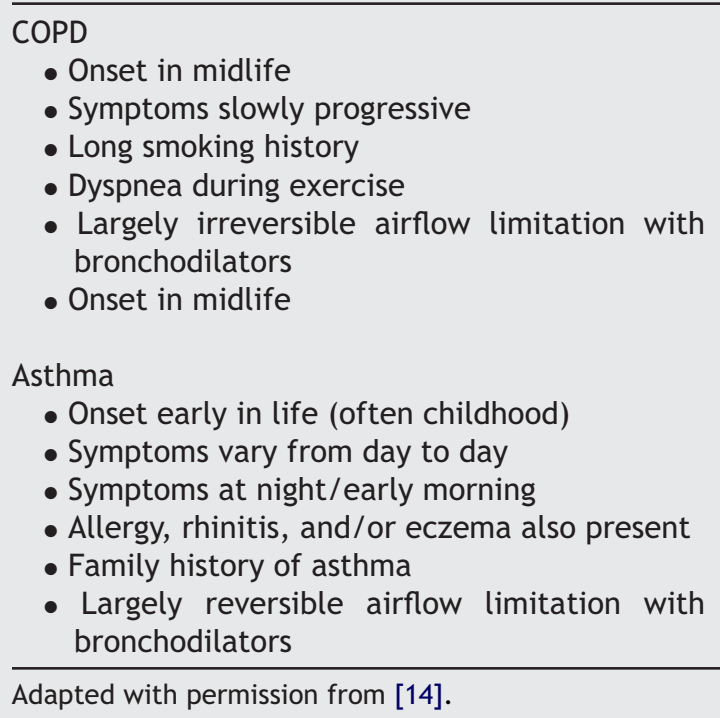

young children, overdiagnosis and unnecessary prolonged treatment may occur due to confusion with other wheezing illnesses, such as viral respiratory infection, or in children with persistent cough $[14,15]$. In older children and adolescents, underdiagnosis is more common, possibly due to the fear of attaching a label of asthma to a child or failure of the child to recognize symntonis as abnormal $[16,17]$. In adults and the biderly, differentiating betweer helorcric obstructive pulmonary disease (COPD) and asthor a hej, De difficult (see Table 3) [18]. For exarnple, smokers with long-standing asthma may retain a diagnosis of asthma when they actually have COPD. In people of all ages, alternative diagnoses such as cardiac disease or cystic fibrosis in the young must be considered, especially in people not responding to asthma-related treatment.

\section{Asthma severity classification}

Despite considerable educational efforts, the asthma severity classification recommended in the GINA and NHLBI guidelines is problematic for many physicians $[3,4,6-8]$. The severity classification has not been validated as a clinical tool, and this may have undermined physicians' belief and confidence in the utility of this aspect of the guidelines. [19] Moreover, there are a number of practical difficulties in applying the severity classification [7,19-21].

The severity classification must be applied to patients in the absence of therapy. This is not possible in many cases even at initial diagnosis. In addition, the severity classification is not designed to allow the effect of pharmacotherapy to be assessed over time - a key clinical objective. There is also increasing evidence that severity is dynamic and variable, making the asthma severity classification for a patient at a single point in time misleading and unhelpful in adjusting therapy [22-24].

Severity classification also has limited reliability. A survey of 14 board-certified pediatric allergists and pulmonologists, based on eight case studies, found poor agreement between the physicians on the asthma severity classification ( $\kappa$ statistic $=0.29$ [ $<0.4$ is poor agreement]) [19]. This resulted in considerable variation in the medications suggested for each case ( $\kappa$ statistic $=0.03-0.39$ ). If asthma severity classification cannot be applied reliably by a small group of asthma experts then variations are likely to be far wider in clinical practice, with resulting inappropriate pharmacotherapy.

In primary care, an easy-to-use tool is required that maximizes the ability to choose therapy based on the benefit-to-risk ratio for asthma treatment. To be used, the tool must have relevance to both physician and Fatient. From a practical perspectiver adurescitis the level of control over lasthras signs and symptoms is a redichabie approach with high validity for primary care phvsiridns. [2 Sy Symptom-based guidelines procuced ir Canada have improved primary care physicians' ability to manage asthma, although limited data are available [26-28]. In addition, the International Primary Care Respiratory Group is working on primary care-focused, symptom-based guidelines [20].

\section{Treating asthma as an inflammatory disease}

Airway inflammation occurs at a very early stage in asthma [29], and there is no clear cut-off in severity below which the inflammatory process is not relevant. For example, significant evidence of ongoing airway inflammation was found in a study of 18 patients with asthma who had no symptoms or medication use for the previous year [30]. Chronic inflammation in asthma disrupts normal cellular repair processes, and may lead to airway remodeling with attendant reductions in lung function [31].

Inflammation is an early and continuing process in asthma, and anti-inflammatory treatment with an anti-inflammatory medication should also be early and continuing. In the GINA, NHLBI (USA), Canadian, and most other guidelines, ICS are 
the preferred anti-inflammatory medication $[3,4]$. However, explaining the asthma inflammatory process to patients can be problematic. Some patients may better understand analogies to other common inflammatory processes, for example, the reaction to mosquito bites, or small lacerations. These examples must be relevant to the patient. It is important that physicians ensure that patients understand the underlying inflammatory cause of their disease and its chronicity. We cannot hope that patients will adhere to daily, long-term medication unless they have an appreciation of the importance and need for continuous therapy, even when their symptoms are controlled.

\section{Asthma management}

The GINA and NHLBI guidelines recommend that asthma therapy is initiated to achieve prompt control and is then stepped down once control is achieved $[3,4]$. The aim is to use the minimum effective dose to maintain clinical stability. Stepup therapy for immediate control of symptoms and exacerbations has been shown to be effective [32], and appears to occur frequently $[33,34]$. However, few patients attend a follow-up visit to allow a trial of step-down therapy. Physicians may believe that if something is working they are reluctaric of hange it, and patients may feol that a collow-up visit is neither necessa y rich by are now conrirolled. However Picients irequently step-down or stop therapy on their own without physician consultation. For example, in a recent survey, although $75 \%$ of patients reported using ICS, only $38 \%$ used the ICS on a daily basis as prescribed and $40 \%$ used the ICS only when they had symptoms [35].

Patients generally overestimate the control of their asthma. In the Asthma Insights and Reality surveys, $32-49 \%$ of patients experiencing severe symptoms and $39-70 \%$ of patients with moderate symptoms believed that their asthma was completely or well controlled [5]. Patients' perception of 'normal' may shift in the presence of chronic symptoms, and their expectations of treatment will be lowered. A trial of ICS with or without bronchodilators for at least two weeks, even in patients reporting that their asthma is controlled, may 'reset' their perception of normal and raise their expectations for ICS therapy.

The majority of patients experience mild intermittent or persistent asthma and should achieve symptom control with ICS mono-therapy, ICS being the safest and most effective monotherapy for persistent asthma $[3,4]$. The use of ICS plus long-acting $\beta$-agonist fixed combinations may be appropriate for patients who would otherwise require high-dose ICS for severe or uncontrolled asthma, such as those with daily symptoms [35]. The trend to use combination inhalers as first line therapy in all patients with persistent asthma risks subsequent overtreatment if patients are not stepped down to ICS mono-therapy once symptom control is attained. In general, patients should be started on ICS mono-therapy and the dose titrated to gain control, with add-on therapy considered only if symptoms persist [37]. A more rapid onset of ICS effect could make this easier for both patients and physicians to accept. An alternative approach to enhance rapid improvement is the use of a shortacting bronchodilator once a day while the ICS reaches a clinically effective level, usually 10 to 14 days.

\section{Safety of asthma medications}

No asthma medication is without potential side effects, which in some cases can be serious (Table 4) [4,36]. Titration of pharnacotherapy to the minimum level recuiredifdecitrol symptoms is a key priricipal of asi hma management.

t Locial adverse leffects, such as dysphonia, pharyngitish cicodidiasis and cough, may be $r \in$ SI) proible for a lack of patient adherence to longterm ICS. Patients with certain conditions may be at increased risk of adverse events. For example, oesophageal candidiasis is more prevalent in ICS users who also have diabetes [38]. For children, both parents and physicians often express undue fear of ICS treatment, particularly with regard to its effects on growth, resulting in undertreatment and insufficient medical control of inflammation and symptoms $[36,39,40]$. Unfortunately, as shown by Bellamy and Harris recently [41], physicians may not solicit information adequately enough on patients' experiences or fears of adverse events [41,42].

With currently available ICS, increasing the dose may increase efficacy, but also increases the risk of adverse events. Evidence of the efficacy-to-safety benefit for ICS is usually only available for lowdose therapy, making extrapolation to high doses difficult $[43,44]$. Over-medication with ICS may result from the use of more potent ICS therapies and newer delivery devices, by increasing the relative effective dose received into the lungs and systematic circulation [45]. For example, growth failure in children and adrenal suppression in children and adults have been observed with moderate to high doses of fluticasone propionate 
Table 4 Potential adverse events with anti-asthma drugs.

\begin{tabular}{|c|c|}
\hline Therapy & Potential adverse events \\
\hline Inhaled corticosteroids & $\begin{array}{l}\text { - Cough, dysphonia, oral thrush (candidiasis). } \\
\text { - In high doses systemic effects may occur: adrenal suppression, osteoporosis, } \\
\text { growth suppression, and skin thinning and easy bruising. }\end{array}$ \\
\hline Systemic corticosteroids & $\begin{array}{l}\text { - Short-term use: reversible, abnormalities in glucose metabolism, increased } \\
\text { appetite, fluid retention, weight gain, mood alteration, hypertension, peptic } \\
\text { ulcer and rarely aseptic necrosis of femur. } \\
\text { - Long-term use: adrenal axis suppression, growth suppression, dermal thinning, } \\
\text { hypertension, diabetes, Cushing's syndrome, cataracts, muscle weakness, and } \\
\text { in rare instances impaired immune function. } \\
\text { - Consideration should be given to coexisting conditions that could be worsened } \\
\text { by systemic corticosteroids, such as herpes virus infections, varicella, } \\
\text { tuberculosis, hypertension, peptic ulcers and Strongyloides. }\end{array}$ \\
\hline $\begin{array}{l}\text { Cromolyn sodium and } \\
\text { nedocromil }\end{array}$ & - 15 to 20 percent of patients complain of an unpleasant taste from nedocromil. \\
\hline $\begin{array}{l}\text { Inhaled long-acting } \\
\beta_{2} \text {-agonists }\end{array}$ & $\begin{array}{l}\text { - Tachycardia, skeletal muscle tremor, hypokalemia, prolongation of QTC } \\
\text { interval in overdose. } \\
\text { - A diminished bronchoprotective effect may occur within } 1 \text { week of chronic } \\
\text { therapy. Clinical significance has not been established. }\end{array}$ \\
\hline $\begin{array}{l}\text { Oral long-acting } \\
\beta_{2} \text {-agonists }\end{array}$ & $\begin{array}{l}\text { - Inhaled long-acting } \beta_{2} \text {-agonists are preferred because they are longer acting } \\
\text { and have fewer side effects than oral sustained-release agents. }\end{array}$ \\
\hline Methylxanthines & 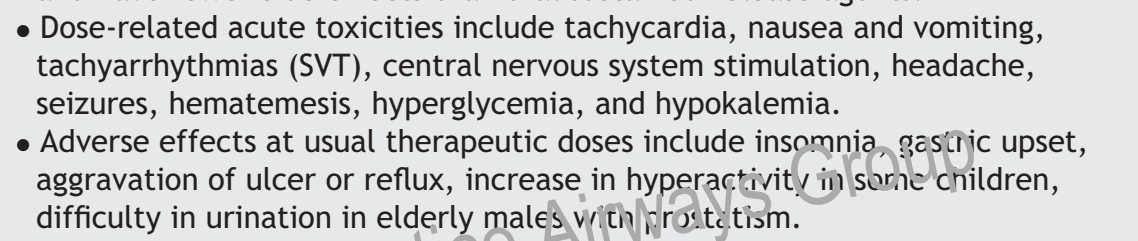 \\
\hline Leukotriene modifiers & 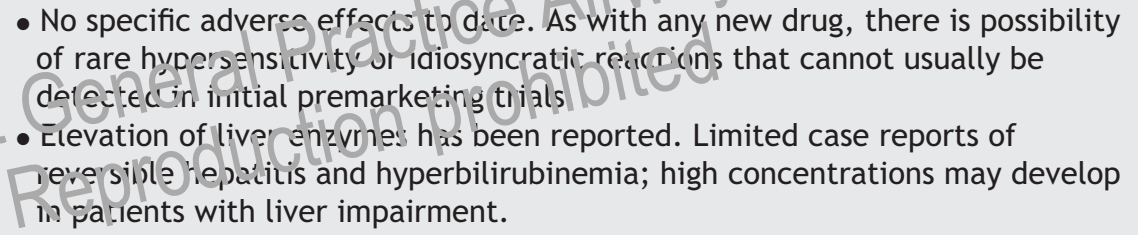 \\
\hline Inhaled $\beta_{2}$-agonists & $\begin{array}{l}\text { - Tachycardia, skeletal muscle tremor, hypokalemia, increased lactic acid, } \\
\text { headache, hyperglycemia. } \\
\text { - Inhaled route, in general, causes few systemic adverse effects. Patients with } \\
\text { preexisting cardiovascular disease, especially the elderly, may have adverse } \\
\text { cardiovascular reactions with inhaled therapy. }\end{array}$ \\
\hline Anticholinergics & $\begin{array}{l}\text { - Drying of mouth and respiratory secretions, increased wheezing in some } \\
\text { individuals, blurred vision if sprayed in eyes. }\end{array}$ \\
\hline
\end{tabular}

Adapted with permission from [4].

$[36,46,47]$. For patients with poorly controlled asthma, overuse of medication may result from increased dose or increased frequency of use in an attempt to control symptoms [48].

Several types of advances in ICS therapy [49] have been accomplished. The initial ICS were in a formulation easily absorbed from the mouth and $\mathrm{Gl}$ tracts, where $30 \%$ to $40 \%$ of each dose was deposited in the mouth and gastro-intestinal (GI) tract [50-52]. Newer formulations have decreased ICS bio-availability outside the lungs, with reduced transport into the circulation and more rapid metabolism by the liver [49-52]. Additional advances have occurred with the development of newer delivery devices [49] that deliver smaller ICS particles. Holding chambers also decrease ICS deposition in the mouth and GI tract [51]. With the importance of ICS at the centre of asthma management, pharmacological strategies to improve safety continue to evolve. For example, an ICS that is delivered to the lungs in an inactive form, and then metabolized to the active form in the lungs, will soon be available. This drug has undetectable serum levels in healthy volunteers [53]. Other new ICS formulations are being considered that increase lung tissue binding to lower the drug delivered to the systematic circulation. [54]. Alternative strategies to lower the 
total daily dose of ICS include the addition of longacting bronchodilators or leukotriene modifiers in people with moderate to severe asthma, but not in those patients with mild persistent asthma [55-58]. Such new agents and new strategies would potentially reduce both the incidence and fear of adverse events due to ICS - an important consideration in achieving patient adherence.

\section{Patient-focused care}

Patients' beliefs regarding diagnosis, prognosis, and the efficacy, necessity and safety of therapy, will determine compliance. Thus, achieving the correct balance of risks and benefits in asthma management requires a patient-focused approach, with high-quality physician-patient communication, continuity of care, and concordance on the goals of asthma therapy leading to an agreed management plan. A multi-disciplinary approach may be a successful strategy in some settings [59]. In addition, the development of communication and teaching skills for physicians and nurses involved in asthma management fulfils a need not often met through formal medical education. Newer educational modalities, such as case-based or video scenario studies, with immediate disfus ion and feedback, may help increase the lisitity of the multi-disciplinary $e^{-a n n}$ to include the concept of concordance pand mutual soabseting with the patient [60].

\section{Conclusions}

Current asthma guidelines are an excellent starting point to direct asthma management, but have practical limitations in primary care, requiring continued efforts to translate evidence-based guidelines into practice. Much of the difficulty in using guidelines is based on the limitations of the severity scoring system in addressing several factors: the variability in asthma symptoms over time; monitoring the impact of pharmacotherapy; and appearing meaningful and relevant to patients and primary care physicians. A focus on asthma control combined with educational efforts to direct patient-focused care should be priorities for primary care asthma guideline translation and management activities. The strengths of existing guidelines such as the hierarchy of recommended pharmacotherapy beginning with ICS, and the preeminence of patient and family asthma education, must be maintained.

\section{Acknowledgements}

This work was supported by a grant from Altana Pharma Limited

\section{References}

[1] Masoli M, Fabian D, Holt S, Beasley R. Global Initiative for Asthma (GINA) Program. The global burden of asthma: executive summary of the GINA Dissemination Committee report. Allergy 2004;59:469-78.

[2] European lung white book. Brussels, Belgium: European Respiratory Society and the European Lung Foundation; 2003.

[3] Global Initiative for Asthma. GINA Workshop Report, Global Strategy for Asthma Management and Prevention, April 2002. http://www.ginasthma.com/workshop.pdf. Updated November 2003. http://www.ginasthma.com/wr_ clean.pdf.

[4] National Asthma Education and Prevention Program. Expert panel report 2 update: guidelines for the diagnosis and management of asthma. Bethesda, MD: National Institutes of Health; 2003.

[5] Rabe KF, Adachi M, Lai CK, Soriano JB, Vermeire PA, Weiss $\mathrm{KB}$, et al. Worldwide severity and control of asthma in children and adults: the global asthma ii sights and reality surveys. J Allergy Clin imm unol 2015, 1 14:40-7.

[6] Cabana ML, Ranc S, Becher OJ, Rubin HR. Reasons fo Dedliactician nonadherence to asthma guidelines. Arch Pediatr Adolesc 11 C 2001;155(9):1057-62.

[7] Doer:Chu! KC, Deterson MW, Dayton CS, Kline JN. Asthma guiderines. An assessment of physician understanding and practice. Am J Respir Crit Care Med 1999;159:173541.

[8] Roghmann MC, Sexton M. Adherence to asthma guidelines in general practices. J Asthma 1999;36:381-7.

[9] Wever-Hess J, Wever AM. Asthma statistics in The Netherlands. Respir Med 1997;91:417-22.

[10] Haahtelaa T, Klaukkab T, Koskelac K, Erholac M, Laitinend LA, on the behalf of the Working Group of the Asthma Programme in Finland. Review Asthma programme in Finland: a community problem needs community solutions. Thorax 2001;56:806-14.

[11] Schermer TR, Jacobs JE, Chavannes NH, Hartman J, Folgering HT, Bottema BJ, et al. Validity of spirometric testing in a general practice population of patients with chronic obstructive pulmonary disease (COPD). Thorax 2003;58:861-6.

[12] Buffels J, Degryse J, Heyrman J, Decramer M, DIDASCO Study. Office spirometry significantly improves early detection of COPD in general practice: the DIDASCO study. Chest 2004;125:1394-9.

[13] Griffiths C, Feder G, Wedzicha J, Foster G, Livingstone A, Marlowe GS. Feasibility of spirometry and reversibility testing for the identification of patients with chronic obstructive pulmonary disease on asthma registers in general practice. Respir Med 1999;93:903-8.

[14] Thomson F, Masters IB, Chang AB. Persistent cough in children and the overuse of medications. J Paediatr Child Health 2002;38:578-81.

[15] Csonka P, Mertsola J, Kaila M, Ashorn P. Regional variation in the diagnosis of asthma among preschool-age children. Pediatr Allergy Immunol 2000;11:189-92. 
[16] Kuhni CE, Sennhauser FH. The Yentl syndrome in childhood asthma: risk factors for undertreatment in Swiss children. Pediatr Pulmonol 1995;19:156-60.

[17] Speight AN, Lee DA, Hey EN. Underdiagnosis and undertreatment of asthma in childhood. $\mathrm{Br}$ Med $\mathrm{J}$ 1983;286:1253-6.

[18] Global Initiative for Obstructive Lung Disease. Global strategy for the diagnosis, management, and prevention of chronic obstructive pulmonary disease. Updated 2003. http://www.goldcopd.com/wr.html.

[19] Baker KM, Brand DA, Hen JJ. Classifying asthma: disagreement among specialists. Chest 2003;124:215663.

[20] International Primary Care Respiratory Group. International Primary Care Airways Guidelines (IPAG). http://www. theipcrg.org/ipag/.

[21] Ting S. Multicolored simplified asthma guideline reminder (MSAGR) for better adherence to national/global asthma guidelines. Ann Allergy Asthma Immunol (2002 Mar) 2002;88(3):326-30.

[22] Calhoun WJ, Sutton LB, Emmett A, Dorinsky PM. Asthma variability in patients previously treated with $\beta_{2}$-agonists alone. J Allergy Clin Immunol 2003;112:1088-94.

[23] Zhang J, Yu C, Holgate ST, Reiss TF. Variability and lack of predictive ability of asthma end-points in clinical trials. Eur Respir J 2002;20(5):1102-9.

[24] Goldman MD, Carter R, Klein R, Fritz G, Carter B, Pachucki P. Within-and between-day variability of respiratory impedance, using impulse oscillometry in adolescent asthmatics. Pediatr Pulmonol 2002;34(4):312-9.

[25] Yawn BP. The impact of childhood asthma on daily life of the family. Primary Care Respir J 2003;12(3):82-5.

[26] Boulet LP, Bai TR, Becker A, Berube D, Beveridge R, Bowie $\mathrm{DM}$, et al. What is new since the last (1999) Cand di.n.

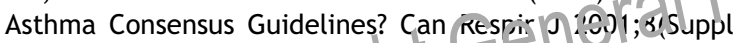
A):5A-27A.

[27] Boulet LP, hillips A, D B drate P, Becker A. Fvalirat on of asthma control by physicians and patien tc: Coinfarron with current guidelines. Can Respir J 2002; $;: 41$ l-23.

[28] Agence Nationale d'Accréditation et d'Evaluation en Santé. Clinical Practice Guidelines. Therapeutic education of the adult and adolescent asthmatic patient. June 2001. Rev Pneumol Clin 2002;58:169-84.

[29] Vignola AM, Chanez P, Campbell AM, Souques F, Lebel B, Enander I, et al. Airway inflammation in mild intermittent and in persistent asthma. Am J Respir Crit Care Med 1998;157:403-9.

[30] van den Toorn LM, Overbeek SE, de Jongste JC, Leman K, Hoogsteden HC, Prins JB. Airway inflammation is present during clinical remission of atopic asthma. Am J Respir Crit Care Med 2001;164:2107-13.

[31] Elias JA, Zhu Z, Chupp G, Homer RJ. Airway remodeling in asthma. J Clin Invest 1999;104:1001-6.

[32] van der Molen T, Meyboom-de Jong B, Mulder HH, Postma DS. Starting with a higher dose of inhaled corticosteroids in primary care asthma treatment. Am J Respir Crit Care Med 1998;158:121-5.

[33] Rowe BH, Edmonds ML, Spooner CH, Diner B, Camargo CAJ. Corticosteroid therapy for acute asthma. Respir Med 2004;98:275-84.

[34] Dinakar C, Reddy M. The yellow zone in asthma treatment: is it a gray zone? Ann Allergy Asthma Immunol 2004;92:7-16.

[35] Anarella J, Roohan P, Balistreri E, Gesten F. A survey of Medicaid recipients with asthma: perceptions of selfmanagement, access, and care. Chest 2004;125:135967.
[36] Robinson JE, Angelini BL, Krahnke JS, Skoner DP. Inhaled steroids and the risk of adrenal suppression in children. Expert Opin Drug Saf 2002;1(3):237-44.

[37] Bateman ED, Boushey HA, Bousquet J, Busse WW, Clark TJ, Pauwels RA, et al. Can guideline-defined asthma control be achieved? The Gaining Optimal Asthma controL study. Am J Respir Crit Care Med 2004;170(8):836-44.

[38] Kanda N, Yasuba H, Takahashi T, Mizuhara Y, Yamazaki S, Imada Y, et al. Prevalence of esophageal candidiasis among patients treated with inhaled fluticasone propionate. Am J Gastroenterol 2003;98:2146-8.

[39] Yoos HL, Kitzman H, McMullen A. Barriers to antiinflammatory medication use in childhood asthma. Ambul Pediatr 2003;3:181-90.

[40] Peterson-Sweeney K, McMullen A, Yoos HL, Kitzman H. Parental perceptions of their child's asthma: management and medication use. J Pediatr Health Care 2003;17: $118-25$.

[41] Bellamy D, Harris T. Poor perceptions of asthma control: results of the International Control of Asthma Symptoms (ICAS) GP survey. Primary Care Respir J 2005;14(4): 202-8.

[42] Yawn BP, Yawn RA. Measuring asthma quality in primary care: can we develop better measures? Respiratory Medicine Journal. 2005. In press.

[43] Powell H, Gibson PG. Inhaled corticosteroid doses in asthma: an evidence-based approach. Med J Aust 2003;178:223-5.

[44] Masoli M, Holt S, Weatherall M, Beasley R. Dose-response relationship of inhaled budesonide in adul asthma: a metaanalysis. Eur Respir J 2004,23.5J?- (3) U P

[45] Wilson JM, Ro'Je' ICII C': Whaled steroids - too much of a fc Od Euing? Wed J Aust 2002;177:288-9.

46] Wong JY, Zacharin//is, Hocking N, Robinson PJ. Growth and adr all Sc p pression in asthmatic children on moderate - hist doses of fluticasone propionate. J Paediatr Child Health 2002;38:59-62.

[47] Todd GR, Acerini CL, Ross-Russell R, Zahra S, Warner JT, McCance D. Survey of adrenal crisis associated with inhaled corticosteroids in the United Kingdom. Arch Dis Child 2002;87:457-61.

[48] Goeman DP, Sawyer SM, Abramson MJ, Stewart K, Thien FC, Aroni RA, et al. Inhaled steroids - too much of a good thing? Med J Aust 2003;178:247.

[49] Newman SP, Busse WW. Evolution of dry powder inhaler design, formulation, and performance. Respir Med 2002;96(5):293-304.

[50] Bowler S. Inhaled Steroids in asthma. Should the doses be reduced? Aust Fam Physician 2002;31(8):746-8.

[51] Cates CJ, Adams N, Bestall J. Holding chambers versus nebulisers for inhaled steroids in chronic asthma. Cochrane Database Syst Rev 2001(2);CD001491.

[52] Chetta A, Morangio E, Olivieri D. Inhaled steroids and airway remodeling in asthma. Acta Biomed Ateneo Parmense 2003;74(3):121-5.

[53] Reynolds NA, Scott LJ. Ciclesonide. Drugs 2004;64:511-9.

[54] Nathan RA, Nayak AS, Graft DF, et al. Mometasone furoate: efficacy and safety in moderate asthma compared with beclomethasone dipropionate. Ann Allergy Asthma Immunol 2001;86(2):203-10.

[55] Bateman ED, Bantje TA, Gomes MJ, et al. Combination Therapy with Single Inhaler Budesonide/Formoterol Compared with High Dose of Fluticasone Propionate Alone in Patients with Moderate Persistent Asthma. Am J Respir Med 2003;2(3):275-81.

[56] Buhl R, Creemers JPHM, Vondra V, Martelli NA, Naya IP, Ekstromt. Once-daily budesonide/formoterol in a single 
inhaler in adults with moderate persistent asthma. Respiratory Medicine 2003;97:323-30.

[57] Bermann KC, Lindemann L, Braun R, Steinkamp G. Almeterol/fluticasone propionate $(50 / 250 \mu \mathrm{g})$ combination is superior to double dose fluticasone $(500 \mu \mathrm{g})$ for the treatment of symptomatic moderate asthma. Swiss Med Wkly 2004;134:50-8.

[58] Bjermer L, Bisgaard $\mathrm{H}$, Bousquet $\mathrm{J}$, et al. Montelukast and fluticasone compared with salmeterol and fluticasone in protecting against asthma exacerbation in adults: one year, double blind, randomized, comparative trial. BMJ com 2003;327:891.

[59] Griffiths C, Foster G, Barnes N, Eldridge S, Tate H, Begum S, et al. Specialist nurse intervention to reduce unscheduled asthma care in a deprived multiethnic area: the east London randomised controlled trial for high risk asthma (ELECTRA). Br Med J 2004;328:144.

[60] Clark NM, Gong M, Schork MA, et al. Impact of Education for Physicians on Patient Outcomes. Pediatrics 1998;101(5):831-6.

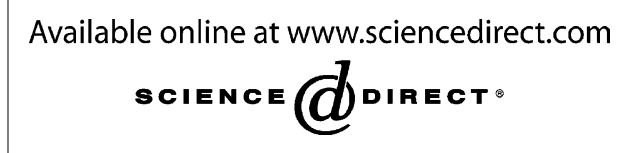

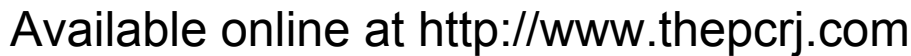

